\title{
Inducible Nitric Oxide Synthase in the Placenta of Pregnant Women with Preeclampsia
}

Presented at 1st International Online BioMedical Conference

ORIGINAL

\begin{abstract}
Juan Carlos Medrano-Rodríguez ${ }^{1}$, Eduardo Medrano-Cortés ${ }^{2}$, Christian Starlight Franco-Trejo ${ }^{3}$, Hilda Saray Contreras de la Fuente 4
\end{abstract}

\section{Abstract}

Preeclampsia (PEC) is the cause of fetal and maternal death. Inducible nitric oxide synthase (iNOS) found in macrophages, smooth muscle cells and endothelial cells. The main objective was to detect the fluorescence iNOS in placenta. Cotyledons cuts were made, they were placed in 10\% formalin. And on the slides washed with buffer solution, oxygenated water with methanol, using $10 \%$ pig serum, anti iNOS Rabbit pAb solution, streptavidin-fluorescein. Microscope Carl Zeiss and Image-Pro 7.0 software was used. Placentas of pregnant women with PEC without pathology were analyzed. Increased uptake of fluorescein in erythrocytes of women without PEC was found, patients who developed PEC was remarkable decreased uptake of fluorescein. Decreasing iNOS activity is evident in preeclampsia.

\section{Keywords}

Inducible Nitric Oxide Synthase; Placenta; Pre-Eclampsia.

\section{Introduction}

During pregnancy, changes in blood pressure is a major cause of maternal and fetal death worldwide, $12 \%$ of all pregnancies develop preeclampsia (PEC) $[1,2,3,4,5,6]$.

The enzyme endothelial nitric oxide synthase (eNOS) generates nitric oxide continuously, producing vasodilation $[7,8]$. The inducible isoform (iNOS) is it found in macrophages, smooth muscle cells and endothelial cells, and other locations as platelets, hepatocytes, tumor cells and lymphocytes $[9,10]$. Finding increased expression of iNOS and eNOS 
in placenta of women with PEC [11]. Perhaps related to alterations in the bioavailability of nitric oxide, being the inflammatory process induces iNOS [12].

Meanwhile, in experimental mice models it has shown that deficiency of eNOS causes decreased blood flow to the uterus [13]; exists also the possibility of reducing iNOS expression caused by adenosine [14].

The main objective of this work was to detect iNOS with fluorescein in placental tissue.

The samples were washed with PBS solution, 7.2 $\mathrm{pH}$, three times for 2 minutes, subsequently treated with hydrogen peroxide at 3\% with methanol, for 15 minutes at room temperature, to prevent endogenous peroxidase activity, after this phase was again washed three times for 2 minutes.

The fabric was covered with pig serum (Rockla$\mathrm{nd}^{\circledR}$, D305, Lot \# 421) 10\% solution in sterile PBS for 30 minutes at room temperature, as a preventive measure for nonspecific binding, washing again, as mentioned in the previous step. The was tissue immediately covered with a solution containing antibodies anti-inducible nitric oxide synthase (Calbiochem ${ }^{\circledR}$, Cat No. 482728, Rabbit anti-iNOS pAb.) diluted 1: 500 with sterile PBS solution for one hour at room temperature. After washing again with PBS, for 30 minutes, the tissue was covered with streptavidin-fluorescein (Calbiochem ${ }^{\circledR}$, Cat No. 189,734) diluted 1:100 with sterile PBS solution, washing during the same time, at room temperature, protected from light.

Finally, washed again, and the presence of iNOS was visualized by fluorescence microscope, Carl Zeiss mark and the Image-Pro Plus 7.0 software

\section{Results and Discussion}

The presence of iNOS in placental tissue from pregnant healthy, demonstrated by fluorescein uptake was higher in erythrocytes, opposite to that described by various authors, who point out that there is a greater presence of the enzyme in macrophages and in endothelial cells, endothelial tissue there is little apparent halo, as shown in figure 1.

For samples of placental tissue, from pregnant women with mild PEC, similar uptake of fluorescein compared to pregnant without pathology, that is, there is growing evidence of the presence of the enzyme in the cytosol of the erythrocytes, with notable absence in macrophage, figure 2 .

Figure 1: Pregnant healthy erythrocytes and endothelial halo fluorescein (yellow arrows).

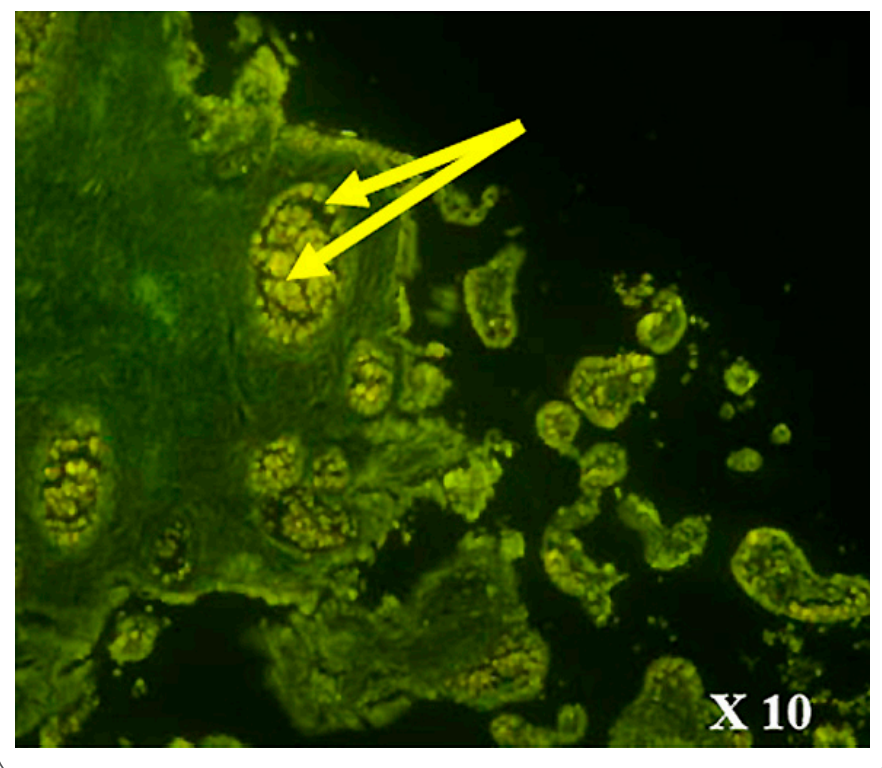

Figure 2: PEC mild, erythrocytes with compound lesser degree than pregnant without PEC (red arrows).

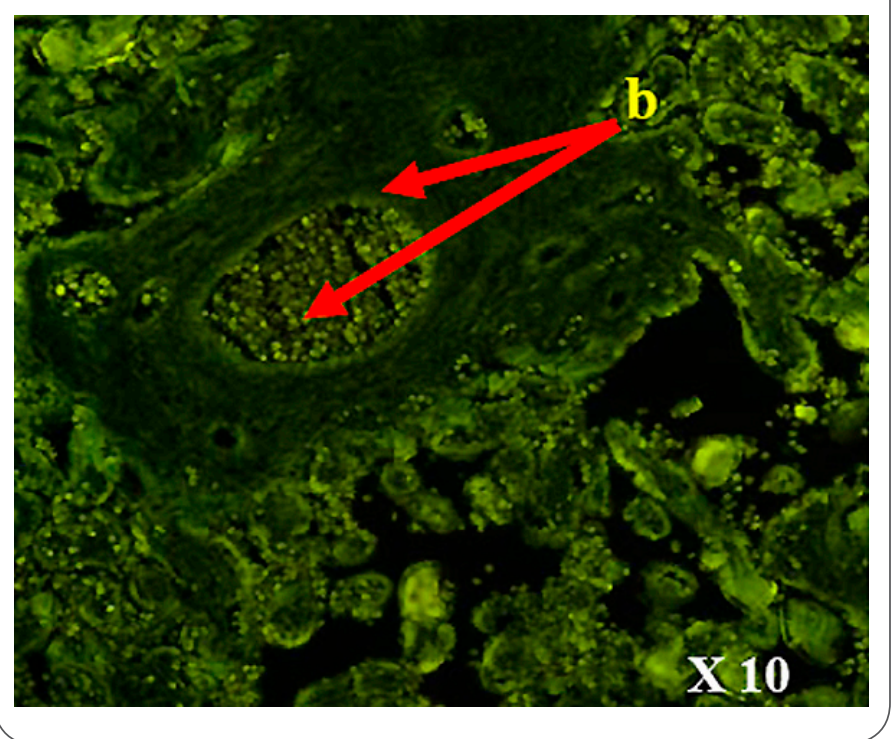


In placental tissue samples belonging to pregnant with PEC moderated is evident the fewer captured of fluorescein in the erythrocyte, figure 3.

Figure 3: PEC moderate, fluorescein decreased uptake by erythrocytes (blue arrows).

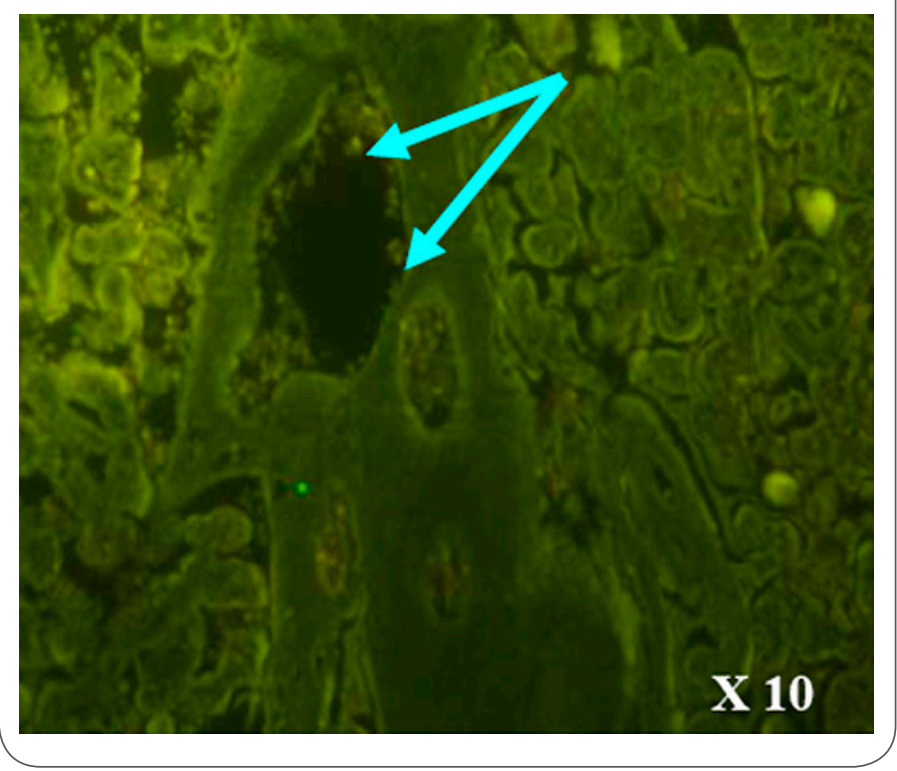

Placental samples from pregnant women with PEC severe, is further reduced level uptake of fluorescein erythrocytes and on endothelial tissue, figure 4,5 .

Figure 4. PEC severe, uptake reduced fluorescein by erythrocytes (white arrows)

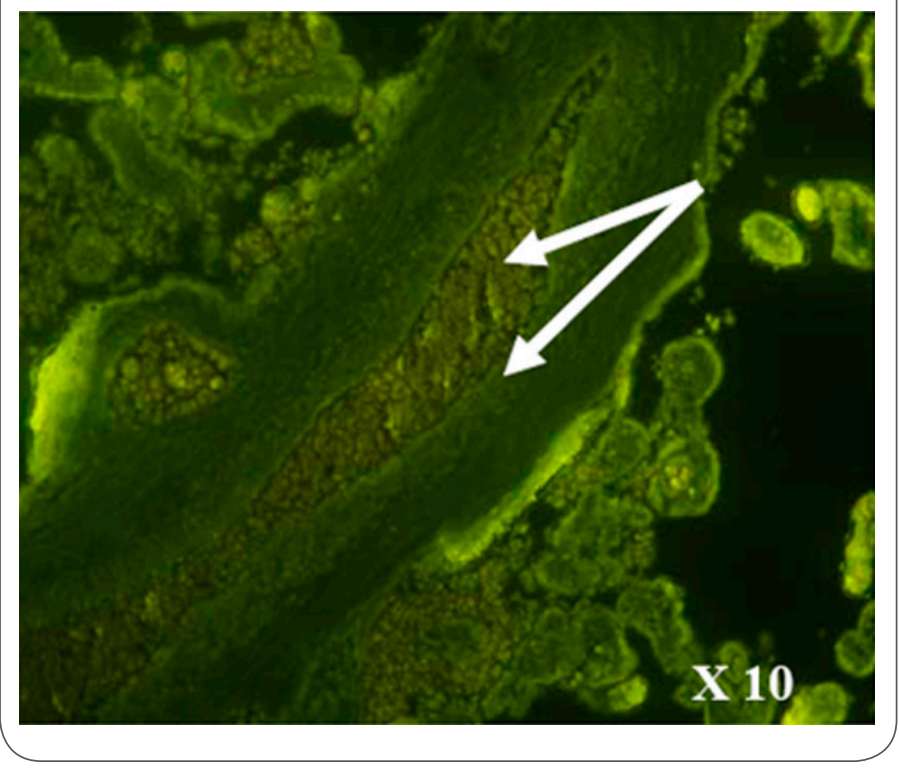

Figure 5: PEC severe, uptake reduced fluorescein by erythrocytes (purple arrows).

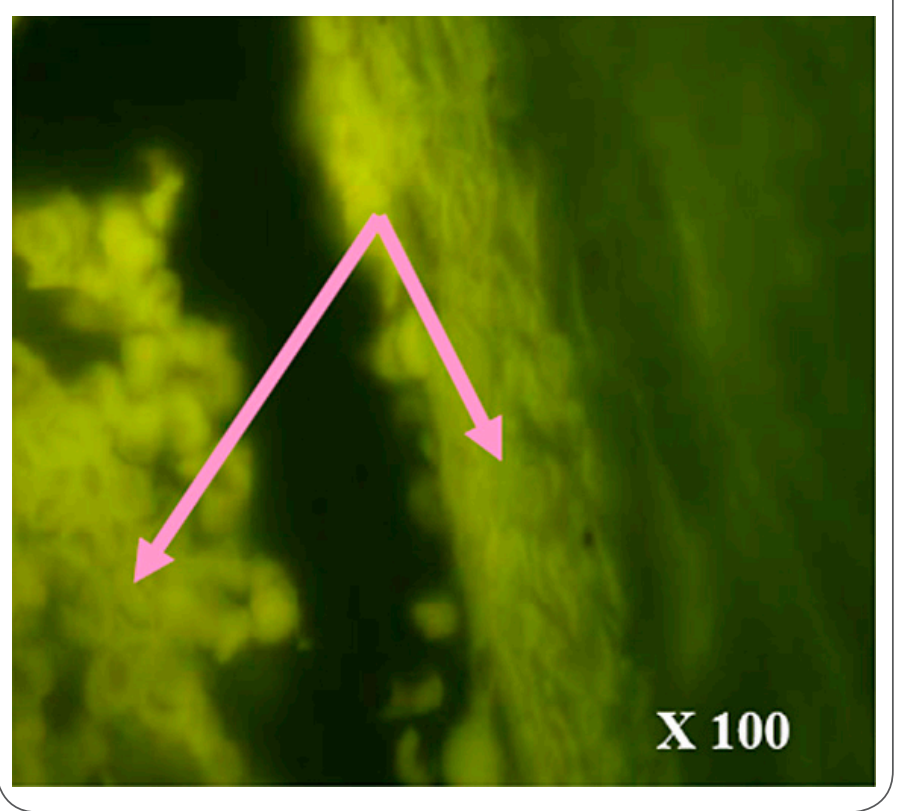

Only one case of PEC severe showed increased accumulation of fluorescein in the endothelial tissue (figure 6, 7), erythrocytes show decreased uptake of the compound, compared with cuts of pregnant without PEC.

Figure 6: PEC severe, increased accumulation of fluorescein in the endothelial tissue (white arrows).

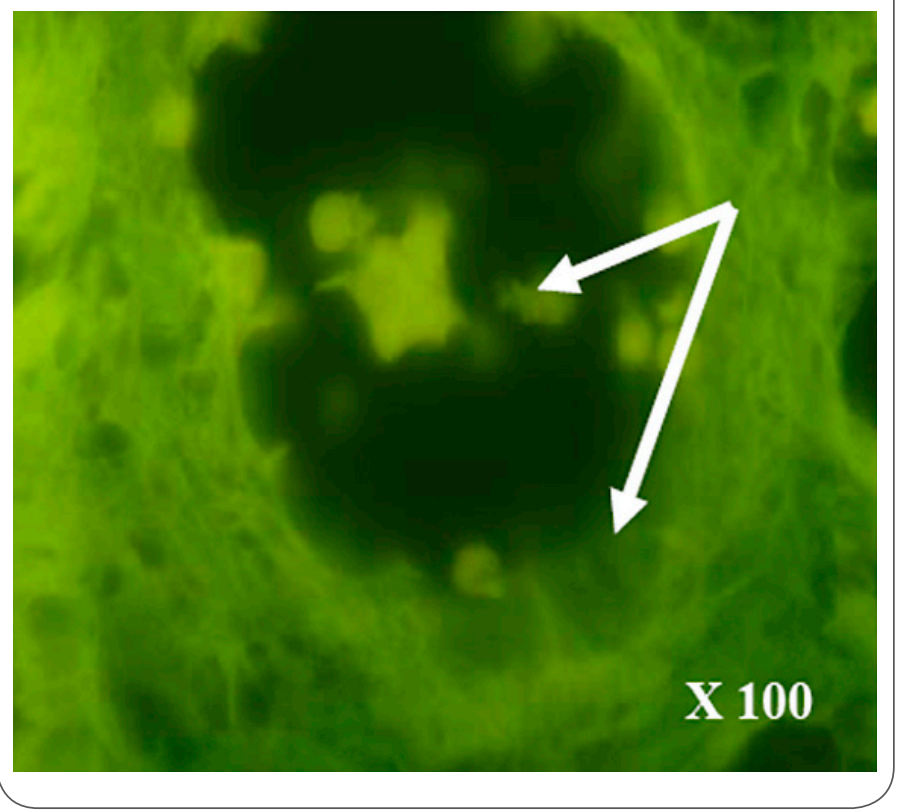


Figure 7: PEC severe, increased accumulation of fluorescein in the endothelial tissue (purple arrows).

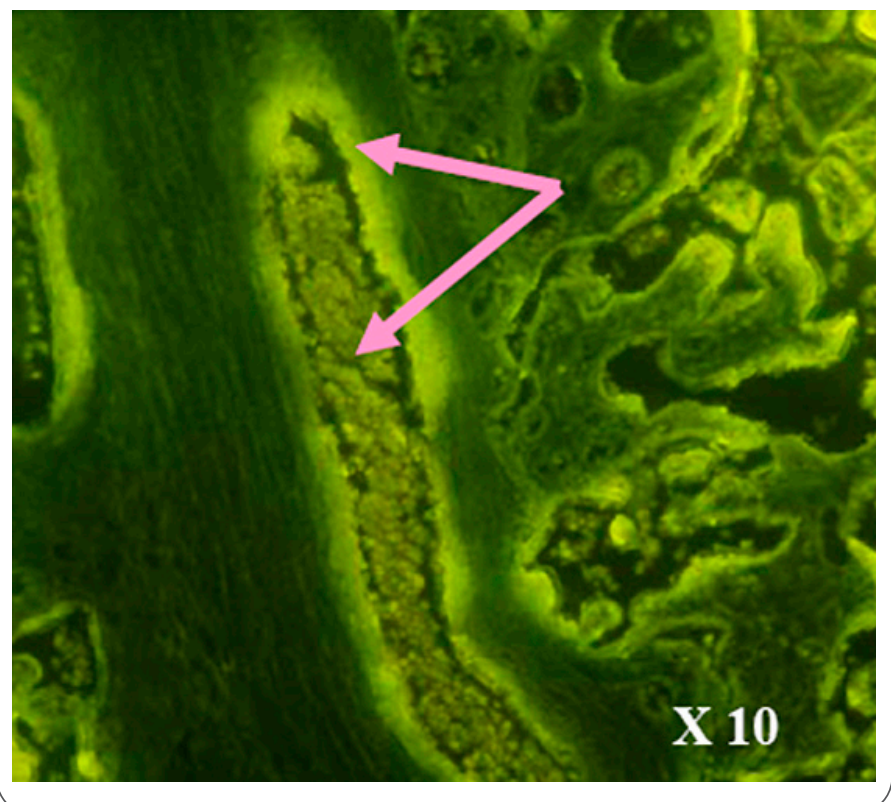

INOS plays an important role in inflammatory processes, since its expression is increased when existing damage endothelium, besides being an essential element for vasodilation [9, 10].

However, there is controversy about the same levels in relation to the PEC, because some studies report increased expression of iNOS, still others have found the opposite [11, 12,13].

According to the results obtained in this study, it is evident the decrease of iNOS, which is higher depending on the severity of the PEC, coinciding with the report of previous studies [14].

The decrease in the expression of iNOS reduced amount of nitric oxide, contributing to the process of vasoconstriction and increase in blood pressure, all known and clinical consequences of PEC.

\section{Conclusions}

There is an obvious decrease in activity of iNOS during preeclampsia, which is a possible explanatory factor on the process of vasoconstriction during pregnancy, manifested by elevated blood pressure.

The technique described allowed achieve the goal, making a notable difference between the normal and the pathological (PEC), highlighting differences by the progress and severity of preeclampsia.

\section{Acknowledgments.}

To the executives of the Hospital of the Women Zacatecana, and women pregnant of the Medical Unit.

\section{References}

1. Quintana NP, Rey DF, Sisi TG, Antonelli CA, Ramos M. Preeclampsia. Revista de Posgrado de la Vía Cátedra de Medicina. 2003, (133): 16-20.

2. Gilbert J. S, Ryan M. J, LaMarca B. B, Sedeek M, Murphy S. R, Granger J. P. Pathophysiology of hypertension during preeclampsia: linking placental ischemia with endothelial dysfunction. Am J Physiol Heart Circ Physiol. 2008, 294(2): H541-H550.

3. Kashiwagi M, Zimmermann R, Beinder E. Pathophysiology of pre-eclampsia: update on the role of nitric oxide. Current Hypertension Reports. 2003, 5: 493-497.

4. Hernández CJ, Ulloa GC, Ojeda VM, Linares MR, et. al. Enfermedad Hipertensiva Gravídica: algunos factores biosociales y obstétricos 1988-1993. Rev. Cubana Obstet. Ginecol. 1999, 25(1): 45-50

5. Moysén JS, Martínez LY, Lechuga QA, Ruiz AR, et. al. Situación psicosocial de las adolescentes y toxemias del embarazo. Salud Pública de México. 2000, 42(2): 99-105.

6. Yu C, Teoh T, Robinson S. Obesity in pregnancy. BJOG. 2006a, 113: $1117-1125$.

7. Rodrigo J, Alonso D, Fernández AP, et. al. El óxido nítrico: síntesis, neuroprotección y neurotoxicidad. Nitric oxide: synthesis, neuroprotection and neurotoxicity. Anales del Sistema Sanitario de Navarra. 2000, 23(2): 195-236.

8. Chambers JC, Fusi L, Malik IS, Haskard DO, et. al. Association of Maternal Endotelial Dysfunction With Preeclampsia. JAMA. 2001, 285(12): 1607-1612. 
9. Mohaupt M. Molecular aspects of preeclampsia. Molecular Aspects of Medicine. 2007, 28: 169-191.

10. Myers J, Mires G, Macleod M, Baker P. In Preeclampsia, the Circulating Factors Capable of Altering In Vitro Endothelial Function Precede Clinical Disease. Hypertension. 2005, 45: 258263.

11. Alemán I, Alex R, Ramírez M, Hung A y Ramírez C. Expresión de las óxido nítrico sintasas constitutiva, endotelial e inducible en pacientes venezolanas con preclampsia. Invest Clin. 2018, 49(3): 321

12. Matsubara K, Higaki T, Matsubara Y, Nawa A. Nitric oxide an reactive oxygen species in the pathogenesis of preeclampsia. Int. J. Mol, Sci. 2015, 16: 4600-4614.

13. Kulandavelu S, Whiteley K.J, Qu D, Mu J, Bainbridge S.A, Adamson S.L. Endothelial Nitric Oxide Synthase Deficiency Reduces Uterine Blood Flow, Spiral Artery Elongation, and Placental Oxygenation in Pregnant Mice. Hypertension. 2012, 60: $231-238$

14. Escudero C, Sobrevia L. A Hypothesis for Preeclampsia: Adenosine and Inducible Nitric Oxide Synthase in Human Placental Microvascular Endothelium. Placenta, 2008, doi: 10.1016/j.placenta.2008.02.008

\section{Comment on this article:}

\section{(f) (B) in $8+\mathbf{S}$ P}

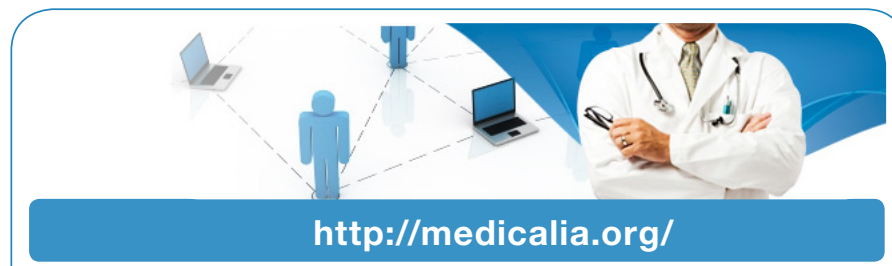

Where Doctors exchange clinical experiences, review their cases and share clinical knowledge. You can also access lots of medical publications for free. Join Now!

\section{Publish with iMedPub}

\section{http://www.imed.pub}

International Archives of Medicine is an open access journal publishing articles encompassing all aspects of medical science and clinical practice. IAM is considered a megajournal with independent sections on all areas of medicine. IAM is a really international journal with authors and board members from all around the world. The journal is widely indexed and classified Q1 in category Medicine. 